\title{
Deconstructing Community for Conservation: Why Simple Assumptions are Not Sufficient
}

\author{
Kerry Ann Waylen • Anke Fischer • \\ Philip J. K. McGowan • E. J. Milner-Gulland \\ Published online: 27 June 2013 \\ (C) The Author(s) 2013. This article is published with open access at Springerlink.com
}

\begin{abstract}
Many conservation policies advocate engagement with local people, but conservation practice has sometimes been criticised for a simplistic understanding of communities and social context. To counter this, this paper explores social structuring and its influences on conservation-related behaviours at the site of a conservation intervention near Pipar forest, within the Seti Khola valley, Nepal. Qualitative and quantitative data from questionnaires and Rapid Rural Appraisal demonstrate how links between groups directly and indirectly influence behaviours of conservation relevance (including existing and potential resource-use and proconservation activities). For low-status groups the harvesting of resources can be driven by others' preference for wild foods, whilst perceptions of elite benefit-capture may cause reluctance to engage with future conservation interventions. The findings reiterate the need to avoid relying on simple assumptions about 'community' in conservation, and particularly the relevance of understanding relationships between groups, in order to understand natural resource use and implications for conservation.
\end{abstract}

Keywords Communities of interest · Political ecology · Conservation and development · Biodiversity conservation . Caste $\cdot$ Socio-ecological systems $\cdot$ Nepal

Electronic supplementary material The online version of this article (doi:10.1007/s10745-013-9594-8) contains supplementary material, which is available to authorized users.

K. A. Waylen $(\bowtie) \cdot A$. Fischer

The James Hutton Institute,

Aberdeen, UK

e-mail: kerry.waylen@hutton.ac.uk

P. J. K. McGowan

University of Newcastle,

Newcastle, UK

K. A. Waylen • E. J. Milner-Gulland

Imperial College London,

Silwood Park, Ascot, UK

\section{Introduction}

Conservation of biodiversity and natural resources is widely agreed as a global priority, not least because it is increasingly understood to be linked with efforts to improve well-being (Hassan et al. 2005). The link with societies and communities is reflected in everything from the 2020 Aichi biodiversity targets (http://www.cbd.int/sp/targets/) through to research funding (e.g., Suich 2012) and the practices of organisations focused on conservation and natural resource management (Levine 2002).

However, the way in which the conservation sector conceptualises and engages with the concept of "community" may be overly simplistic. An influential article by Agrawal and Gibson (1999) suggested that three types of assumption about community are particularly likely and problematic for natural resource management. Firstly, that communities correspond with small spatial units; secondly, that they form a homogenous social structure; and thirdly, that community members share norms. These assumptions may arise from implicit expectations or romanticisms held by outsiders planning interventions (Alcorn 1994). Since then a number of studies and commentaries on conservation have confirmed and elaborated problems of simplistic understandings of community (e.g., Berkes 2004; Kumar 2005; Larson and Soto 2008; Flint et al. 2008). These problems are found even in projects explicitly labelled as community-based conservation or natural resource management (CBC or CBNRM) and may contribute to a growing dissatisfaction with these projects (Dressler et al. 2010; Shackleton et al. 2010).

A central question, but perhaps not one often asked by these projects, is what is 'community', and how can it be understood? Within the social sciences 'community' has long been recognised to be a complex and contested concept (Hillery 1955). People in the same location do have shared experience, but can also have multiple, varied, interacting and potentially conflicting interests and concerns (Fine et al. 2000). Indeed, the idea of 'communities of interest' (Ziller 
2004) suggests that the interests or concerns which pattern social life and interactions (social structuring) of groups of people can be rather more relevant than physical location (Hoggett 1997). However, such insights from social science can be seen as inaccessible by many practitioners within the environmental and conservation sector (Redford 2011), and direct implications for natural resource management may not always be clear.

This paper therefore focuses on exploring the key concept of community by studying a site near Pipar forest in Nepal to illustrate how a nuanced understanding of 'community' aids understanding of natural resource use and hence planning for conservation. We draw strongly on the field of political ecology - the study of the interdependence, constructions and dynamic interactions between the human and natural worlds (Robbins 2003) - which has highlighted how different interest and power groups within and beyond communities produce conflicts and interactions that strongly influence the social and ecological outcomes of conservation projects (e.g., Brown 1998; McCarthy 2000). The focus of our study thus lies on one of the three aspects of the critique raised by Agrawal and Gibson (1999), namely the often-assumed structural homogeneity of communities. We particularly considered the caste system (which in Nepal incorporates ethnic groups) in addition to a range of potential demographic and place-based influences, since although this is officially outlawed as a basis of discrimination, it is still understood to fix at birth many aspects of social status (Bista 2004).

Our research aims were (1) to describe local social heterogeneity and key differences structuring interactions between groups of people at the study site, (2) to explore how these differences affect resource use by these groups, and (3) to reflect upon the implications of these findings for the planning of conservation interventions which aim to engage with a 'community'.

\section{Study Site Background}

The Pipar forest, within the famous Annapurna Conservation Area, western Nepal, is a site of special conservation interest because it contains an unusual diversity of vegetation types, related to its altitudinal range, from $1,300 \mathrm{~m}$ to $4,000 \mathrm{~m}$ (Poudyal 2005). The $43 \mathrm{~km}^{2}$ Pipar forest is of particular interest because five of Nepal's six pheasant species are found there, including the Himalayan Monal (Lophophorus impejanus), the national bird of Nepal (Lelliot 1981). The area has therefore been the target of a small but long-running community conservation initiative by the UK-based World Pheasant Association (WPA). This has mostly involved the WPA supporting education (funding local teachers and school infrastructure) in exchange for promises of pro-conservation behaviour. The impetus for this study came from the WPA's desire to better understand the people living in the area and reflect on future work, rather than a wish to evaluate previous work.

Behaviours at this site that could be of conservation concern are pheasant hunting, degradation of high altitude habitats by grazing and collection of wild vegetables and medicinal herbs, particularly during the birds' breeding season (Gyawali 2004). In an early example of community engagement by a conservation agency, in the late 1970s, the WPA asked people in the northern end of the Seti Khola valley, below the Pipar forest, if they would be prepared to carry out these activities only for their own needs and not during the breeding season, and - if they agreed - what they would like in return. The residents requested support for education and so, since that time, the WPA has provided financial support for school infrastructure and teachers, gradually expanding their support to villages further south. By 2008 WPA had provided educational support throughout the whole valley. In the most northerly village, it has also supported a wildlife guard/liaison officer since 1983, and funded bird and vegetation surveys that are now carried out by Nepali researchers affiliated to WPA.

The WPA operates within the wider context of the Annapurna Conservation Area Project (ACAP), created in 1986. ACAP is the largest area in the world specifically designated for integrated conservation and development activities, with the stated objective of improving human livelihoods (Robinson and Redford 2004). The considerable resources and administrative structures of ACAP have influenced the study site. Conservation Area Management Committees (CAMCs) have been set up, and ACAP is locally understood to have helped support some development initiatives, in particular biogas toilets and the provision of water taps. However, ACAP's influence is less marked than in areas such as Ghandruk where it has operated the longest and promoted tourism (Baral et al. 2010). Furthermore, a recent Maoist insurgency that caused civil unrest from the late 1990s meant some of ACAP's institutions and initiatives had lapsed at the time of study. For these reasons, this study does not attempt to evaluate the effect of existing or previous interventions at the case study site, but these interventions provide a context within which the study aims to inform future efforts and interventions.

Numerous other authors have evaluated ACAP's progress and impacts (e.g., Stevens 1997; Baral and Stern 2010) and we do not attempt to replicate these studies here. It is relevant to note, however, that these evaluations have often found positive ecological outcomes from ACAP (e.g., Bajracharya et al. 2005) but more variable social impacts (e.g., Mehta and Kellert 1998; Mehta and Heinen 2001; Spiteri and Nepal 2008). Positive social impacts and attitudes towards conservation are prerequisites for long-term conservation success (Coppolillo and Borgerhoff Mulder 2005). The effect of the recent Maoist insurgency on ACAP activities may illustrate 
this point, since effective resource management was maintained only in those villages where ACAP had fostered local empowerment and commitment to conservation (Baral and Stern 2010; Baral et al. 2010).

\section{Methods}

The study used a mixture of qualitative and quantitative data collection methods to explore social structuring and environmental perceptions of people in villages near to a conservation intervention, the WPA Pipar Project. The Pipar forest lies on a ridge of Macchapuchare mountain $\left(28^{\circ} 24^{\prime} \mathrm{N}, 83^{\circ} 57^{\prime} \mathrm{E}\right)$. Below this ridge, the Seti Khola river runs south, fed by the Sardi Khola and Birjung Khola, and flanked by the villages where this study was conducted. Below the valley lies the large tourist town of Pokhara, which was around $2 \mathrm{~h}$ travel by bus from the south of the valley. North of here, further access to the valley was by foot. Northern villages and those lying higher up the sides of the valley are more remote from Pokhara, but northerly locations have better access to Pipar forest. The study area was defined by all villages from this valley accessible to Pipar forest within one day. Data were collected from all parts of the valley.

Qualitative data were generated using Rapid Rural Appraisal (RRA) in 2007 and 2008. RRA is a loose set of principles and approaches focused around encouraging participation and progressive learning (Chambers 1992; Kapila and Lyon 1994) one hour was used to identify and explore social structuring and links between interest groups within villages in the valley, in terms of their natural resource use. Ideas associated with conservation cannot be assumed to be uncontested or universally shared (West 2006) but we discussed experiences and understanding of conservation and found the term was generally conceptualised similarly to the way it is understood by Europeans, probably due to the influence of ACAP. Questionnaire surveys in 2008 were then used to elicit quantitative data based on the qualitative results of the RRA work.

Ethical guidelines were followed at all times during research, with informed verbal consent being sought before all interviews and discussions. Each literate participant received an information sheet that described the work and its intended outputs. Copies of information collected during RRA, such as village maps, were given to the village. Participation in the questionnaire survey was rewarded by a small present of gift-wrapped sweets.

\section{Rapid Rural Appraisal}

RRA sessions involved focus group discussions and were held in groups of three to five people. Group composition was carefully considered to maximise the range of views across groups, and to encourage freedom of expression within each group. Within any one location there was usually a men's group, a women's group, a youth group, children, and a separate group for people of low socioeconomic status (often the occupational castes).

Participation and interest were encouraged through the use of visual techniques, which also allowed discussion to be understood by all participants, including the non-literate. A research assistant who was trained and briefed on the research aims and RRA principles acted as translator and accompanied the researcher (KAW) at all times. Discussion topics included: village life and events; livelihoods and the role of natural resources in livelihoods; perceptions and uses of local natural resources; and perceptions, understanding and involvement with conservation activities. Activities used to explore these topics and promote discussion included group construction of timelines, ranking, mapping, listing, scoring and flow-diagrams. To triangulate findings, one topic was approached in different ways by the same group, and the same topics were covered by different groups.

\section{Questionnaire Survey}

In 2008 a questionnaire survey was used both to gather sociodemographic data about the valley's population and to link this to views on nature and conservation issues. This was based on the RRA findings, and further developed during extensive discussion with the local population, pre-testing and piloting in an adjacent valley. In any survey, respondents can be biased to report what they believe the interviewer wants to hear. This was taken into account in the design and implementation of the questionnaire. During questionnaire design, we used extensive informal discussion with a variety of testers to discuss how and why they gave certain responses. We also used interviews with key informants and informal observations of everyday life in the study site to triangulate those aspects of views and relevant behaviours. The final questionnaire contained a variety of questions to probe single issues, give opportunity for 'reality checks', and was administered by enumerators who had received careful training in how to discuss the questionnaire and research with participants, including this issue.

Three enumerators worked separately to interview one adult from each of 661 randomly selected households. The sample represents a high proportion of the 1478 households known to be within the valley in 2001 (Central Bureau of Statistics 2001), even more so as the civil unrest is thought to have since caused emigration. Household size in the sample ranged from 1 to 18 people, with a mean size of 6.0 including 1.9 children under 16. Most respondents (70 \%) had always lived in their village, and many of the immigrants were women who had moved upon marriage. Religious beliefs followed a similar pattern to census data, with Hinduism most common (74 \%) followed by Buddhism (17\%). Some respondents described themselves as 'Hindu-Buddhist', reflecting the mixing of religions in Nepal. Table 1 lists topics in the questionnaire. 
Table 1 Questionnaire items used to collect information about a) demographic and household attributes b) views relevant to nature and conservation

\begin{tabular}{|c|c|c|}
\hline Topic & Variable & Details of question and answer operationalisation \\
\hline \multirow{10}{*}{$\begin{array}{l}\text { Socio-demographic data } \\
\text { and livelihoods }\end{array}$} & Age & Age of primary respondent \\
\hline & Gender & The gender of primary respondent \\
\hline & Family size & The number of adults, and children. \\
\hline & Livelihoods & $\begin{array}{l}\text { The primary and secondary occupations or livelihood activities for all adult members of } \\
\text { the household }\end{array}$ \\
\hline & Education & Open format, later coded into a five-level scale from 1 (illiterate) to 5 (degree held). \\
\hline & Religion & $\begin{array}{l}\text { Open format, since although Hindu, Buddhism were main responses expected, some } \\
\text { respondents described themselves as 'Hindu-Buddhist' and there were some Christians. }\end{array}$ \\
\hline & Caste level & $\begin{array}{l}\text { Open format description of caste group, later recoded into } 1 \text { (low caste, used for } \\
\text { occupational castes), to } 3 \text { (high caste, Brahmin Chhetri castes). }\end{array}$ \\
\hline & Wealth & $\begin{array}{l}\text { One item, four level-response from high to low wealth relative to others in area. Asking } \\
\text { how 'comfortable' the respondent felt their household was relative to others in their } \\
\text { community, on a 4-level scale. }\end{array}$ \\
\hline & Household size & $\begin{array}{l}\text { Household size includes members working abroad but does not include family members } \\
\text { usually based in another household. }\end{array}$ \\
\hline & Remoteness & $\begin{array}{l}\text { Typical travel time by foot and bus from village of respondent to reach the nearest large } \\
\text { town of Pokhara, in minutes. }\end{array}$ \\
\hline Conservation support & $\begin{array}{l}\text { Local conservation } \\
\text { support }\end{array}$ & $\begin{array}{l}\text { One item, "what do you think of the amount of effort that is put into conservation in this } \\
\text { valley?" Response coded on a five -point Likert-type response format and extensively } \\
\text { 'reality checked' through discussion. Earlier related items were not reality checked and } \\
\text { or were unduly influenced by enumerators' perceived interests. }\end{array}$ \\
\hline
\end{tabular}

\section{Data Analysis}

Local views elicited during RRA group work were recorded in detailed hand written notes during the meeting, together with comments about group dynamics. These notes were later typed into Word and imported into Nvivo (QSR International 2008), where they were coded by subject to aid searching and information retrieval. Questionnaire data were stored, coded and presented with Microsoft Excel, with SPSS 17.0 used to generate statistics (SPSS Incorporated 2008).

\section{Results}

Shared Strategies and Resource Use Throughout the Valley

Throughout the valley the dominant occupation was agriculture, with $96 \%$ of households maintaining crops and sometimes livestock, often as an addition to paid employment. With the exception of teaching, all of the desirable jobs which paid a high rate of income could be pursued only by moving out of the village (Fig. 1); indeed $48 \%$ of households had members working abroad. The need for cash investment and/or a good education limited further pursuit of these options. Livelihoods that depended on working for others in the village were not desirable. For example, agricultural labour for others was performed only by those without land. Tourism is important as a source of income in other areas of ACAP (Spiteri and Nepal 2008) but here involved less than $1 \%$ of households.

Local natural resources were essential to all livelihoods, predominantly as an input for feeding livestock and fertilising fields. The forest was highly valued in every area for the collection of edible vegetables, fodder for livestock and for cultural reasons (such as religion, recreation or place attachment). The forest was visited to collect firewood, fruit, vegetables, medicinal herbs, meat and 'Nigalo' (bamboos used to make household implements such as baskets, furniture and household structures such as fences). Respondents in villages at the northern end of the valley also discussed weaving a rough fabric from Pua (Girardinia diversifolia) for their own wear, although they preferred to purchase clothes made of other materials. Many of the conservation concerns in the region relate to direct use of species from the forest, such as hunting and the harvest of wild plants (e.g., McGowan 2004).

As common in other parts of rural Nepal, many livelihoods comprised multiple activities. Many minor or seasonal activities involved the use of natural products: for example, bamboo weaving occurred during the dry season and collecting wild plants for vegetables and medicine. Such jobs were not highly regarded, but brought useful extra income during periods of hardship. Depending on the value of wild products, they were consumed, exchanged locally or traded to other parts of the valley and beyond. Vegetables could be traded in local markets, or bartered for biscuits or 
Fig. 1 Major livelihood options, desirability and constraints, as identified by a youth group (7 participants).

The lines joining boxes link to constraints associated with each livelihood option. The dollar symbols represent the financial gain from each livelihood option. "Pokhara-bus" means making a living driving a vehicle for goods in the town of Pokhara; "Abroad other" is emigration to India or Gulf states to do manual labour; "Weave doko" is creating baskets (and other household products) from bamboo strips

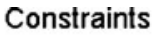

Jobs

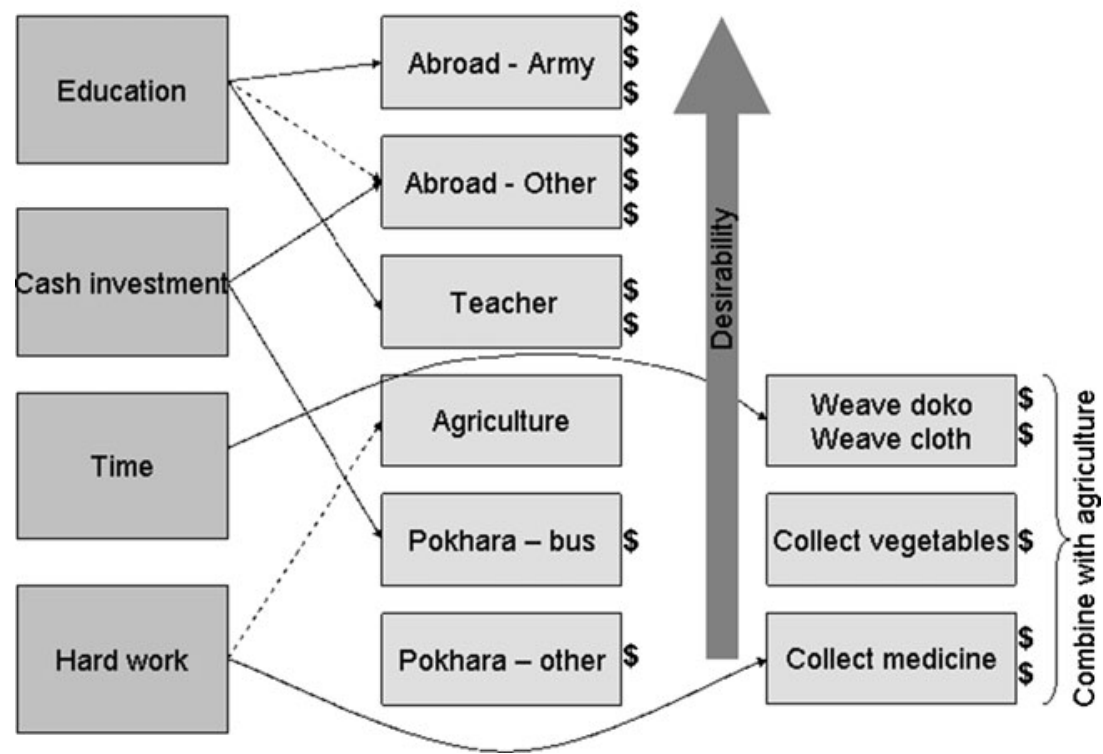

milk at the local shop. Valuable vegetables and medicines could also be sold further afield, such as markets in the town of Pokhara. Through these exchanges of resources between producers and consumers, no part of the valley - and no livelihood strategy - was entirely self-sufficient or isolated from others.

\section{The Effects of Social Structuring on Livelihood Strategies}

Location The remoteness of villages in the valley was varied. As measured by the typical time taken to walk the shortest path, and then take a bus (with no wait) in the dry season, travel time to Pokhara ranged from 1 to $3.5 \mathrm{~h}$. Some of those in the southern end of the valley were therefore able to visit town regularly, which entailed greater options for access to markets, healthcare and employment.

Wealth Respondents often judged that there was significant variation in wealth between households. Participants in focus group discussions concurred that poorer people were less likely to own land, more likely to depend on working for others, their houses were often smaller and more crowded, and their children did not attend school for long. In discussions about status and wealth in the area, local people found it useful to categorise households into four levels of wealth or status, which subsequently formed the basis of a question in the survey: $30 \%$ of respondents were identified in the survey as "comfortable', with $58 \%, 7 \%$ and $5 \%$ respectively identifying as 'coping', 'coping with difficulty' or 'coping with extreme difficulty'.

Caste As in much of Nepal, the population of the valley was socially and ethnically diverse. In the Pipar area, it was possible to categorise castes into three groups ordered by status. These were: Brahmin and Chhetri (high caste, IndoAryan ethnic origins), Gurung and Magar (Tibeto-Burman ethnic groups, mid-status caste), and occupational castes (mainly Damai, Kami and Sarki, low caste, also of IndoAryan origins). The most common caste in the sample was the Gurung ethnic group (22\%) followed by Magar (19\%) and Brahmin (18\%) leaving the lower castes as minorities within all settlements. No village was comprised entirely of households of one caste, although the more remote villages were slightly less diverse.

Local people perceived the caste system to be the most fundamental source of differences between people in the valley. The questionnaire data revealed that caste structured many aspects of everyday life and household composition: for example, higher caste was associated with slightly smaller family sizes (Spearman rank, Rho $=-0.093, p=0.017$, $N=661$ ), and fewer children (Rho $=-0.189, p=0.000$, $N=661$ ).

Discrimination against lower caste groups evidently continued despite its illegality. For example, lower caste individuals were not allowed into the houses of the higher castes, and if they touched water it was contaminated for the higher castes. Although some higher castes blamed lower castes for learnt helplessness, they also freely remarked that the lower castes were "dirty". The lower castes perceived unfairness:

Discrimination, as well as present poverty, prevents us from improving our position. There is suppression by other castes. Our condition is worsening and we are living like slaves, living in the dark. We cannot get loans because we do not have the deposit needed. We have no money and are very poor. 
Nobody trusts us, so will not lend us money. We have no roads, high illiteracy and suffer from suppression, discrimination. It is hard to send children to school.

Participants in focus group discussion held with Damai caste members in Ghachok VDC.

Walking around larger settlements it became clear that people from minority castes always lived together, forming separate social units. This had implications for the pattern of development interventions in the valley. In the more southerly, accessible parts of the valley, some amenities such as biogas toilets, electricity lines and water taps were becoming available, but they tended to be routed only to the areas where the higher castes lived. For example, within $20 \mathrm{~min}$ walk of a low caste household with no amenities were some high caste households with a satellite telephone, biogas toilets, direct access to a semi-paved track, a shared water tap and access to the new electricity supply.

In concordance with these observations, focus group discussions and the questionnaire survey results confirmed that higher caste status was positively associated with higher wealth status (Spearman Rho $=0.125, N=659, p=0.001$ ). Of course, this was not an absolute relationship: many high caste households did not consider themselves as rich, whilst some low caste respondents did not see themselves as particularly poor.

Caste and Livelihood Strategies Caste also determined many livelihood practices: for example, of the 28 individuals recorded by the questionnaire as teachers or in government employment, none were from the lower castes. Some associations between caste and occupation had positive connotations - the Gurung ethnic group has traditionally been associated with soldiering, particularly with the most prestigious job possible, a Ghurkha in the British army. However, the specialised jobs of blacksmith, mason, and tailor were the exclusive preserve of the lower castes, and were perceived as extremely low status jobs. Agricultural labour was disproportionately common in the lower castes $\left(\chi^{2}=30.2, \mathrm{df}=2\right.$, $p<0.0001)$. Focus groups explained that this was because those with the lowest status were unlikely to own their own land. This also meant they were unable to access loans from the agricultural development bank to set up new businesses, as they could offer no deposit or collateral. These various constraints meant that their livelihood strategies were considerably more constrained than for higher status groups (Table 2).

Caste and Resource Access All households in the study area needed wood for fuel for cooking and lighting, but less was needed by households with access to biogas. Within one administrative unit, Ghachok VDC, KAW stayed in the house of a high caste (Brahmin) individual who was employed as a teacher but also active in numerous committees. Through this contact, it was possible to meet all individuals in positions of influence with local government organisations, and they were all males of high caste (Brahmin or Chhetri). This meant that all activities mediated by local administrations, including natural resource governance (e.g., forest user groups, CAMC committees), were biased in favour of those castes. A frequent complaint of the lower (occupational) castes was thus that "nobody will hear us".

Brahmin and Chhetri have more control and rights over the forests, they think it is their ancestral right. Lower caste people don't have a place in the forest. We have no community forest and need permission to use. We go higher [up in the mountains].

Key posts in the CAMC are held by Brahmin and Chhetri. The funds collected are used for these people (e.g., wards 1, 2, 3). Anyone should be able to use any forest e.g. people from ward 7 should be able to use forest in ward 1. We have no private forest so we need to go high for timber.

Discussion on constraints on natural resource use by a Sarki group (low caste men).

The lower castes also claimed to hold only limited access to wood resources, even having to sneak into nearby forests at night, because the forests designated for their use were inconveniently located very far away. As this group also tended to own less land, and so fewer trees, they struggled to secure access to firewood.

Table 2 Livelihood options listed in order of desirability, as perceived by two different caste groups living in close proximity to one another. All of the options ranked by the low caste group fit within the fifth ranked option of the high caste group

\begin{tabular}{lll}
\hline Rank & Chhetri (high caste) & Damai (low caste) \\
\hline 1 & Private and government employment, e.g. teacher, government, health agencies, bus driver & Ploughing \\
2 & Own business, e.g. rice mill, saw mill, alcohol brewing, medicinal shops, veterinary shops, transport company & Planting \\
3 & Working abroad & Portering \& carrying stones \\
4 & Agriculture, vegetable farming, animal husbandry & Mason \\
5 & Manual labour, e.g. ploughing, planting, portering, mason, also blacksmith, carpenter, tailoring & \\
\hline
\end{tabular}


Social differences and Livelihood Strategies Shape Natural Resource Use

There were three categories of resource use that could be potential targets for conservation interventions: collection of NTFPs for medicinal use, hunting of galliform species, and collection of NTFPs to cook as vegetables. The use of these resources was often part of livelihood strategies but perceived differently by different interest groups, mainly depending on their wealth and caste.

Wealth Richer individuals in less remote (southerly) parts of the valley perceived forest products as an optional supplement to their livelihoods and lifestyles. For example, a high caste group of men in the south identified the local forests as useful for providing wild vegetables, fruits and medicines. However, such respondents often did not harvest these products themselves. Instead, female family members might pick fruit and vegetables, or all these products could be purchased locally, using cash or bartering domestically grown produce. Firewood was collected from privately owned land, or again could be bought from others. Many well-off people stated that they had no practical need for forest products. For example, many focus group participants said they grew more than enough vegetables in their domestic plots to feed themselves comfortably. However, many still did consume wild products, motivated by a preference for the taste or their perceived properties: nearly all interviewees valued wild vegetables for the "variety" they provided in diets, and also for their "special taste". Wild meat was also thought to be more tasty, as well as having medicinal properties, such as the ability to alleviate back pain. As a result, wild food was not necessarily a substantial part of the diet (as indicated by food ranking exercises; for example, wild vegetables typically contributed only $20 \%$ of vegetable intake) but were nearly always reported as desirable. For example, women in the remote village of Kabre unanimously preferred to receive a gift of wild vegetables, meat and spices, rather than domestic equivalents.

Caste The preference for wild food was especially marked in people of the Gurung ethnic group (mid-level caste). When asked if any caste group had a special association with natural resources, the Gurung people were nominated both by themselves and the other castes. Their use of resources was thought to be higher, since they brew 'raksi', the potent local spirit which requires copious amounts of firewood for distillation. The Gurungs and to a lesser extent Magars - were also thought to be good at hunting and to have the most definite knowledge of, and penchant for, wild foods. Hunting with dogs took place both for meat and as recreation. Studies of other Magar communities have found belief in multiple spirits dedicated to good hunting (Gurung 1989). For other groups, the motivation was only to produce meat, using traps placed during visits to the forest for other purposes, such as when taking livestock to graze. It was usually difficult to hold lengthy discussions about the subject, because hunting was widely understood to be illegal, and therefore a sensitive topic. Rarely would focus group participants directly confess to hunting, but they were often willing to identify hunters from other villages.

We don't know how to kill here...hunters are old and youths are not interested, and there is increased forest. In the past [before 20 years ago] everything above was fields (rice, maize, millet), and pasture at the top. We had to go very high to see the animals, now tiger and bear come into maize fields, they kill goats and dogs. We can get dry meat from Kabre and Bharaburi. One kilogramme of Jharal [Himalayan Tahr, Hemitragus jemlahicus] costs about 500 rupees [US\$6.50].

\section{Focus group discussion in a predominantly Gurung- Magar village in the north-east of the valley.}

By triangulating all reports it became clear that Gurungs and Magars in the northern end of the valley were particularly likely to go hunting, with some of the meat being dried and traded within the valley, or carried out to urban centres. For example, the participants in the above discussion pointed out that the village of Chaunglung had a high number of men employed in the British and Indian armies, so households receiving their remittances could afford to buy meat. There may also have been some hunters that came in from adjacent valleys, and visitors from town would pay local people to hunt meat.

Links Between Groups The topic of hunting also showed how those harvesting wild resources were often motivated by practical need, since the resources could be sold to those who had a cultural preference for wild foods. For example, for a Damai (low caste) teenager in Chaunglung, his slingshot could bring a useful if infrequent source of income:

Once I killed a Pura [hill partridge, Arborophilia torqueloa] and sold it here for 350 rupees [\$4.80], I bought clothes for my family. I caught a Phisto [Prinia spp.] but it is only worth one bite!

Discussions about wild vegetables were slightly less sensitive and therefore occurred more often. Here again, the same links between practical need and cultural preference were found: finding and selling wild vegetables could be a very useful source of income for those who were not 
wealthy. Various pieces of evidence collected during fieldwork suggested there was a strong market for wild foods, that led some people to supplement their incomes by collecting and trading them (see Supplementary material). In particular, the vegetable Tusa (Himalayacalamus spp.) was much in demand. This was available only in the higher areas above the valley but it was perceived as a delicacy by nearly all, and particularly esteemed by the Gurung and Magar castes. For example, the teenager who discussed hunting also collected vegetables:

Tusa is collected for selling within the village, mostly by poor people. They go once a week in season. Other vegetables are not sold. They go to the village 2-3 times per week to get vegetables to eat. A little bunch of Tusa [makes ring between thumb and forefinger] costs 5-10 rupees [US\$0.07-0.14]. For example, we didn't have rice one day, so we collected some Tusa and sold it and got rice.

Demand was both local and urban, with vegetables sold in the same village, in villages further south in the valley, and in the town of Pokhara. Medicines were sold illegally; however this was often difficult to discuss, and perhaps underreported. For poor landless people, this source of income may be particularly useful during the dry seasons, when little labour is required on farms.

Tusa is collected before the rainy season. Other vegetables collected are Neuro, Kourila (which follow the same pattern) and Caulisaag, as they come into season. Everybody collects these for themselves, and some collect for selling.

We don't collect much medicinal herbs, it is not legal.

We ask the forest guard for a little for ourselves. We will go to collect [medicinal] herbs if we are not too busy. People who stay in Goths can collect more. There are gaps in our collection time in summer (due to leeches), and in winter (due to cold).

A group of men from the Sarki (low caste) group, who were poor but not the lowest status group in their area. Goths are high altitude herding huts.

However, collecting wild plants was less important for the very poorest in the southerly areas, from where it was a long walk to areas containing wild vegetables. In the south, individuals of the Damai caste who spent all their time labouring for others also claimed to have both "no time" to look for wild fruits, vegetables or medicines, and also "no idea" of where these plants could be found.

It could not be assumed that all low caste individuals were engaged in finding wild natural resources to sell to the higher castes. The very poorest could not afford guns or the time to lay and maintain traps, so they were also unlikely to be hunters. Where the poor and low caste did harvest resources, it was usually to sell or exchange, to supply the demands of others in their own and nearby villages, and beyond (Table 3).

\section{Experience and Perceptions of Conservation Initiatives}

The majority of questionnaire respondents expressed support for either continuing (38\%) or increasing (52\%) local conservation efforts, even though this followed a discussion of how investing more effort in conservation could mean less investment in other local initiatives such as infrastructure improvement. There was a slight positive relationship between supporting increased conservation efforts and

Table 3 The pattern of natural resource use and harvesting by different social groups in the Seti Khola valley. Caste is linked with status, for example most individuals of the occupational castes have low wealth. Arrows represent resource flows

\begin{tabular}{|c|c|c|}
\hline \multirow[b]{2}{*}{ Social group } & \multicolumn{2}{|c|}{ Collection and consumption of resource } \\
\hline & Firewood & Wild vegetables, medicines and meat \\
\hline Low status & $\begin{array}{l}\text { Required by all. Wood is collected or if no access } \\
\text { then bought. }\end{array}$ & $\begin{array}{l}\text { Vegetables collected usually for sale. Very poorest } \\
\text { may have less time to collect any. }\end{array}$ \\
\hline Mid status & Required by all, Gurung caste may use more for & May collect and buy. \\
\hline & brewing spirits. Wood is collected and bought. & $\begin{array}{l}\text { Gurung caste especially likely to favour wild } \\
\text { products and also to hunt. }\end{array}$ \\
\hline High status & $\begin{array}{l}\text { Wood is required by most, but some have access } \\
\text { to alternative fuel sources and/or their own private } \\
\text { wood supplies. }\end{array}$ & $\begin{array}{l}\text { Collection only occasional. Buy wild products } \\
\text { from others to satisfy preferences. }\end{array}$ \\
\hline $\begin{array}{l}\text { Beyond the } \\
\text { valley }\end{array}$ & No demand. & $\begin{array}{l}\text { Demand from nearby town for wild vegetables and } \\
\text { meats. Some international demand for some } \\
\text { medicinal herbs. }\end{array}$ \\
\hline
\end{tabular}


higher caste (Spearman rank, Rho $=0.105, N=659, p=0.007$ ) but no correlation with wealth $(\mathrm{Rho}=0.051, N=657$, $p=0.190$ ). In both questionnaire responses and focus group discussions, a wide range of opinions about conservation was found in all locations and social groups. Many reported involvement in conservation activities, although questionnaire respondents could often specifically recall only involvement in tree planting activities organised by ACAP.

However, interactions between caste groups and resource access had affected involvement in conservation activities, and people's potential responses to future conservation interventions. Some respondents who were not high caste said that in future they would not contribute to something from which they probably would not benefit. They reported that in the past they had given time to help the planting of 'Utis' (Alnus nepalensis) but now that these tree stands were maturing, they were excluded from taking firewood from them whilst others were not.

When the questionnaire survey asked how the practice of conservation could be improved, only eight respondents (none of them high caste) reacted by calling for nepotism and corruption to be reduced. Many others made more oblique references to corruption or elite capture, or accepted it as a way of life. For example, a Magar (mid caste) respondent felt it was a problem, but was not hopeful of a solution:

Leaders will take. But no one will do anything. They get money and increase the size of their stomachs. All are autocrats and feudals. Who will act? What will be done for the uneducated and illiterate?

Where there was considerable experience of development interventions in the lower half of the valley, the poor had also become, sceptical, saying: "lots of organisations come and ask us but our life standards are still low". Low caste people alleged that "elite people show us [to demonstrate poverty to outsider agencies] but then use us to make money". This group was now very hostile to outside interventions, regardless of their purpose. KAW, and to a lesser extent the Nepali enumerators, were often faced with hostility or even violence when attempting to contact the most deprived groups for the purposes of this research. Engaging with these groups would be difficult for any future interventions.

\section{Discussion}

This study's description of life and livelihoods at the site of a conservation intervention in Nepal demonstrates that simplistic conceptions of community are insufficient. Not only is there strong social structuring (via wealth, caste, and livelihoods) but this also affects attitudes and behaviours that are directly and indirectly relevant to conservation. This lends support for exploring the nuances of social heterogeneity and processes that may connect people, rather than assuming that all the people near a conservation site are a cohesive unit (Agrawal and Gibson 1999).

Other studies from Nepal have noted strong social structuring through caste and elite capture (e.g., Shrestha et al. 2010) but this study is unusual in directly demonstrating why structuring needs to be explored in order to understand both natural resource use and the interactions between social structuring and conservation interventions. For example, supply and demand drove resource exchanges between low and high status groups, with harvesting of wild plants for vegetables often carried out by low status individuals, but in response to a cultural preference that encouraged wealthy households to buy wild foods as a delicacy. Some demand also came from towns beyond the study site: this acts as a reminder of the potential significance of extra-local processes (Berkes 2007), though these were not the focus of this study. Meanwhile, past interactions with other groups, and outsiders, may shape involvement in future conservation initiatives. Therefore, the results suggest it is productive to focus on interests and interest groups, rather than equating community with place (Ziller 2004). Spatial location is not irrelevant - it determines, for example, proximity to natural resources or markets - but its implications for resource use and conservation depend on social processes and structure.

As Agrawal and Gibson (1999) originally said, local people cannot be idealised or simplified as one single small homogenous group with shared norms. It is unlikely that the word 'community' could or should be abandoned. However, our attempts to explore social structuring support Agrawal \& Gibson's recommendations for taking a political approach to deconstructing the concept, to consider the roles of multiple interests and actors, local processes and institutions. To achieve this, and to overcome the tendency for simplifications in conservation (Brown 2002) we suggest it may be useful to seek relationships which make the links between social heterogeneity, processes and institutions. For example, in this study it was the interaction of supply and demand, constrained by rules on resource-access, which determine the harvesting of wild plants as herbs and vegetables. Furthermore, these resource exchanges were often driven by cultural norms and preferences, not just material needs (as in other situations e.g., East et al. 2005).

The specific example of this study also demonstrates how understandings about community and resource use can be used by agents seeking to promote equitable conservation and sustainable resource use. For example, an intervention designed to conserve an over-harvested wild plants in this area might take into account both supply and demand: On the demand side, the idea of introducing new vegetable 
crops has already been discussed by the WPA, but it would be important to explore the possibility of introducing vegetables which are perceived as a delicacy and so act as adequate substitutes for wild foods. On the supply side, it would be important that the very poor landless groups who currently gain benefits from supplying wild plants are not further disadvantaged either by the intervention itself removing their livelihood, or by their reluctance to engage in any alternative livelihoods based on a legacy of past experiences of elite capture and perceived voicelessness. Achieving ecological objectives may be challenging, but without care, interventions focused only on these objectives may have negative social consequences, reinforcing existing inequities (e.g., Spiteri and Nepal 2008), which in itself can jeopardise other goals (Klein et al. 2007).

To understand the complexity of community, and to underpin socially-appropriate interventions, a mix of discursive participatory methods (some of which informed this study) can promote engagement and mutual learning (e.g., Larson et al. 1998; Spiteri and Nepal 2006). The development literature (e.g., Holland and Campbell 2005) has long been attuned to challenges of engaging with communities and power imbalances. This, and rights-based approaches (Campese et al. 2009), may be of assistance in identifying approaches that overcome romanticisms and avoid exacerbating inequities. Exploring construction of environmental identities ('environmentality') may also be relevant to further exploring the nuances of social complexity and change as it relates to conservation understandings and engagement (Agrawal 2005).

\section{Conclusion}

In 1999 Agrawal and Gibson argued that the conservation sector often employed simplified and unsatisfactory understandings and assumptions about community. Since then there has been more evidence and more commentary on this theme, but such simplifications may still persist in conservation practice (perhaps even in the term 'community based conservation' which entered the conservation consciousness relatively recently; Western et al. 1994).

The key contribution of this paper is to explore these more nuanced understandings of community for a particular case study, and consider how these affect natural resource use, and hence the options for conservation interventions. This study particularly supports the need to expect and explore social heterogeneity and multiple interests, rather than equating community with place (e.g., Bray 2009). However, as resource use and conservation outcomes also depend on past and present links between social groups, we suggest a focus on relationships is necessary to achieve a sufficiently nuanced understanding of community for conservation.
Acknowledgments Great thanks are due to the hosts and participants of fieldwork in Nepal. Fieldwork was made possible by the permission of the Annapurna Conservation Area Project of the National Trust for Nature Conservation, Nepal, and the assistance of R.Marston, P.Sherpa, R.Sherpa, R.Tamrakar, U.Thapa and A.Subedi. K.Marshall and RW.Slee and two anonymous reviewers provided useful comments on the manuscript. KAW was supported by studentship PTA-036-2006-00023 from the Economic and Social Research Council and Natural Environment Research Council, United Kingdom. WPA is grateful to the numerous donors who have supported its work in Pipar since 1978. EJMG acknowledges the support of a Royal Society Wolfson Research Merit award.

Open Access This article is distributed under the terms of the Creative Commons Attribution License which permits any use, distribution, and reproduction in any medium, provided the original author(s) and the source are credited.

\section{References}

Agrawal, A. (2005). Environmentality: Technologies of government and the making of subjects. Duke University Press, Durham.

Agrawal, A., and Gibson, C. C. (1999). Enchantment and disenchantment: The role of community in natural resource conservation. World Development 27(4): 629-649.

Alcorn, J. B. (1994). Noble savage or noble state? Northern myths and southern realities in biodiversity conservation. Ethnoecológica 2(3): 7-19.

Bajracharya, S. B., Furley, P. A., and Newton, A. C. (2005). Effectiveness of community involvement in delivering conservation benefits to the Annapurna Conservation Area, Nepal. Environmental Conservation 32(3): 239-247.

Baral, N., and Stern, M. J. (2010). Looking back and looking ahead: local empowerment and governance in the Annapurna Conservation Area, Nepal. Environmental Conservation 37(1): 54-63.

Baral, N., Stern, M. J., and Heinen, J. (2010). Growth, Collapse, and Reorganization of the Annapurna Conservation Area, Nepal: an Analysis of Institutional Resilience. Ecology and Society 15(3): 10.

Berkes, F. (2004). Rethinking community-based conservation. Conservation Biology 18(3): 621-630.

Berkes, F. (2007). Community-based conservation in a globalized world. Proceedings of the National Academy of Sciences of the United States of America 104(39): 15188-15193.

Bista, D. B. (2004). People of Nepal. Ratna Pustak Bhandar, Kathmandu.

Bray, D. (2009). From Displacement-based Conservation to Placebased Conservation. Conservation and Society 7(1): 11-14.

Brown, K. (1998). The political ecology of biodiversity, conservation and development in Nepal's Terai: Confused meanings, means and ends. Ecological Economics 24(1): 73-87.

Brown, K. (2002). Innovations for conservation and development. The Geographical Journal 168: 6-17.

Campese, J., Sunderland, T., Greiber, T. and Oviedo, G. (eds.) 2009 Rights- based approaches: Exploring issues and opportunities for conservation. Centre for International Forestry Research and IUCN - World Conservation Union. Bogor, Indonesia

Central Bureau of Statistics. (2001). National report 2001. Government of Nepal, National Planning Commission Secretariat, Central Bureau of Statistics. [WWW document]. URL http://www.cbs.gov.np/national_report introduction.php

Chambers, R. (1992). Rural appraisal: Rapid, relaxed and participatory. Institute for Development Studies, Brighton.

Coppolillo, P., and Borgerhoff Mulder, M. (2005). Conservation: Linking Ecology, Economics, and Culture. Princeton University Press, Woodstock. 
Dressler, W., Buscher, B., Schoon, M., Brockington, D., Hayes, T., Kull, C. A., McCarthy, J., and Shrestha, K. (2010). From hope to crisis and back again? A critical history of the global CBNRM narrative. Environmental Conservation 37(1): 5-15.

East, T., Kumpel, N. F., Milner-Gulland, E. J., and Rowcliffe, J. M. (2005). Determinants of urban bushmeat consumption in Rio Muni, Equatorial Guinea. Biological Conservation 126(2): 206-215.

Fine, M., Weis, L., Weseen, S., and Wong, L. (2000). For whom? Qualitative Research, Representations, and Social Responsibilities. In Denzin, N. K., and Lincoln, Y. S. (eds.), The handbook of qualitative research. Sage, London, pp. 107-131.

Flint, C. G., Luloff, A. E., and Finley, J. C. (2008). Where is "Community" in community-based forestry? Society and Natural Resources 21(6): $526-537$.

Gurung, H. (1989). Nature \& culture. Suroj Gurung, Kathmandu.

Gyawali, N. (2004). Study on impact of summer grazing and collection of non-timber forest products in Pipar, Annapurna Conservation Area, Nepal. World Pheasant Association, Fordingbridge.

Hassan, R. M., Scholes, R., and Ash, N. (eds.) (2005). Ecosystems and Human Well-being: Current State and Trends : Findings of the Condition and Trends Working Group of the Millennium Ecosystem Assessment. Island Press, Washington, D.C.

Hillery Jr., G. A. (1955). Definitions of community: areas of agreement. Rural Sociology 20(2): 111-123.

Hoggett, P. (ed.) (1997). Contested Communities: Experiences, struggles, policies. Policy Press, Bristol.

Holland, J., and Campbell, J. (eds.) (2005). Methods in development research, combining qualitative and quantitative approaches. ITDG Publishing, Rugby.

Kapila, S., and Lyon, F. (1994). People-oriented research. Expedition Advisory Centre Royal Geographical Society, London.

Klein, J., Reau, B., Kalland, I., and Edwards, M. (2007). Conservation, development, and a heterogeneous community: The case of Ambohitantely Special Reserve, Madagascar. Society and Natural Resources 20(5): 451-467.

Kumar, C. (2005). Revisiting 'community' in community-based natural resource management. Community Development Journal 40(3): 275-285.

Larson, A. M. and Soto, F. (2008). Decentralization of Natural Resource Governance Regimes. In Annual Review of Environment and Resources, Annual Reviews, Palo Alto, pp. 213-239.

Larson, P. S., Freudenberger, M., and Wyckoff-Baird, B. (1998). WWF integrated conservation and development projects: Ten lessons from the field 1985-1996. WWF-US, Washington, D.C.

Lelliot, A. (1981). Studies of Himalayan pheasants in Nepal with reference to their conservation. Thesis submitted for the degree of Master of Science: Durham University, UK.

Levine, A. (2002). Convergence or Convenience? International Conservation NGOs and Development Assistance in Tanzania. World Development 30(6): 1043-1055.

McCarthy, J. (2000). Wild logging': the rise and fall of logging networks and biodiversity conservation projects on Sumatra's rainforest frontier. Occasional Paper No. 31, Bogor, Indonesia: CIFOR (Centre for International Forestry Research).
McGowan, P. (2004). 25 years involvement at Pipar, central Nepal Himalayas: WPA's longest running project. Annual Review of the World Pheasant Association 2003/2004 edition: 59-69.

Mehta, J. N., and Heinen, J. T. (2001). Does community-based conservation shape favorable attitudes among locals? An empirical study from Nepal. Environmental Management 28(2): 165-177.

Mehta, J. N., and Kellert, S. R. (1998). Local attitudes toward community-based conservation policy and programmes in Nepal: a case study in the Makalu-Barun Conservation Area. Environmental Conservation 25(4): 320-333.

Poudyal, L. P. (2005). A study of floral diversity and grazing impacts in Pipar Pheasant Sanctuary, Nepal. Thesis submitted for the degree of Bachelor of Science: Institute of Forestry, Tribhuvan University, Pokhara, Nepal.

QSR International (2008). NVivo 8. QSR International, Melbourne.

Redford, K. H. (2011). Misreading the conservation landscape. Oryx 45(3): 324-330.

Robbins, P. (2003). Political ecology. Blackwell Publishing, Oxford.

Robinson, J. G., and Redford, K. H. (2004). Jack of all trades, master of none: Inherent contradictions among ICD approaches. In McShane, T. O., and Wells, M. P. (eds.), Getting biodiversity projects to work: Towards more effective conservation and development. Columbia University Press, Chichester, pp. 10-34.

Shackleton, C. M., Willis, T. J., Brown, K., and Polunin, N. V. C. (2010). Reflecting on the next generation of models for community-based natural resources management. Environmental Conservation 37(1): 1-4.

Shrestha, U. B., Shrestha, B. B., and Shrestha, S. (2010). Biodiversity conservation in community forests of Nepal: rhetoric and reality. International Journal of Biodiversity and Conservation 2(5): 98-104.

Spiteri, A., and Nepal, S. K. (2006). Incentive-based conservation programs in developing countries: A review of some key issues and suggestions for improvements. Environmental Management 37(1): 1-14.

Spiteri, A., and Nepal, S. K. (2008). Evaluating local benefits from conservation in Nepal's Annapurna Conservation Area. Environmental Management 42(3): 391-401.

SPSS Incorporated (2008). SPSS Statistics for Windows, Release 17.0. SPSS, Chicago.

Stevens, S. (1997). Annapurna Conservation Area: Empowerment, conservation and development in Nepal. In Stevens, S. (ed.), Conservation through cultural survival. Island Press, Washington, D.C., pp. 237-261.

Suich, H. (2012). Ecosystem Services for Poverty Alleviation Conceptual Framework: Poverty. Directorate of the Ecosystem Services for Poverty Alleviation (ESPA) Programme. Available from: http://www.espa.ac.uk/files/espa/Povertyframework.pdf

West, P. (2006). Conservation is our government now: The politics of ecology in Papua New Guinea. Duke University Press, Durham.

Western, D., Strum, S. C., and Wright, M. R. (eds.) (1994). Natural connections: Perspectives in community-based conservation. Island Press, Washington, D.C.

Ziller, A. (2004). The Community is Not a Place and Why it Matters - Case Study: Green Square. Urban Policy and Research 22(4): 465-479. 